\title{
MANAJEMEN KURIKULUM PADA PAUD AS SAKINAH, RUMBAI, PEKANBARU
}

\author{
Suharni \\ Universitas Lancang Kuning \\ suharni@unilak.ac.id
}

\begin{abstract}
The purpose of this study is to find out the Early Childhood Curriculum Management in Pa-As-Sakinah, Rumbai Pekanbaru. The curriculum is one of the tools in the management of education in PAUD to carry out learning in Paud. The curriculum currently implemented in PAUD is K13 and KTSP. This research is evaluative research with a qualitative approach. Data collection is done by observation, interviews, documentation, and questionnaires. The findings of the research carried out, curriculum management carried out at the PAUD As-Sakinah was a combination of KTSP and K13. The K13 and KTSP are almost the same but the K13 method is more directing children to be creative and explore and the teacher is only a facilitator. However, this method has not been fully implemented in PAUD As-Sakinah because teachers are still adjusting to the conditions of children in PAUD As-Sakinah.
\end{abstract}

\section{Key word :management, curriculum,early childhood}

Abstrak : Tujuan penelitian ini untuk mengetahui Manajemen Kurikulum Anak Usia Dini di Paud As- Sakinah, Rumbai Pekanbaru. Kurikulum merupakan salah satu perangkat dalam manajemen pendidikan di Paud untuk melaksanakan pembelajaran di Paud. Kurikulum yang saat ini dilaksanakan di Paud yaitu K13 dan KTSP. Penelitian ini merupakan penelitian evaluatif dengan pendekatan kualitatif. Pengumpulan data yang dilakukan dengan cara observasi, wawancara, dokumentasi, dan angket. Hasil temuan penelitian yang dilakukan, manajemen kurikulum yang dilaksanakan di Paud As- Sakinah gabungan dari KTSP dan K13. Kurikulum K13 maupun KTSP hampir sama namun metode K13 lebih mengarahkan anak lebih berkreativitas dan berekplorasi dan guru hanyalah sebagai fasilitator. Namun, metode tersebut belum sepenuhnya dilaksanakan di Paud As- Sakinah karena guru masih menyesuaikan dengan kondisi anak di Paud As- Sakinah.

Kata kunci : Manajemen, Kurikulum, Pendidikan Anak Usia Dini 


\section{PENDAHULUAN}

Kurikulum adalah suatu system atau program yang di dalam nya terdapat komponen-komponen yang saling behubungan erat dan melengkapi satu sama lain untuk mempermudah dalam aktivitas belajar mengajar. Bentuk-bentuk komponen kurikulum tersebut terdiri dari tujuan, materi pembelajaran, strategi pembelajaran, dan evaluasi. Tujuan dari system kurikulum ini yaitu saling kerja sama seluruh subsistem untuk menuju satu tujuan yang diinginkan. Apabila salah satu komponen kurikulum tidak terlaksanakan dengan baik,maka system kurikum akan berjalan kurang baik dan maksimal.

Setelah dari bentuk kurikulun tersebut,sangat diperlukan pengorganisasian pada seluruh komponen dalam pelaksanaan kurikulum. Dalam proses pengorganisasian ini akan berkaitan erat dengan perencanaan, pengorganisasian, pelaksanaan, dan pengawasan. Sedangkan manajemen adalah salah satu disiplin ilmu yang hasil akhirnya menerapkan proses-proses tersebut. Maka dalam penerapan pelaksanaan kurikulum, seorang yang mengelola lembaga pendidikan harus menguasi ilmu manajemen, baik itu mengurus pendidikan ataupun kurikulumnya.

\section{KURIKULUM}

Secara etimologi, istilah kurikulum berasal dari bahasa yunani, yaitu curir yang artinya "pelari" dan curere yan artinya "tempat berpacu". Istilah kurikulum berasal dari dunia olahraga, terutama dalam bidang atletika pada zaman romawi kuno, dalam bahasa prancis, istilah kurikulum berasal dari kata courier yang berarti berlari. Kurikulum berarti suatu jarak yang harus ditempuh oleh seorang pelari dari garis start sampai dengan finish untuk memperoleh mendali atau penghargaan (Zainal Arifin,2011:2). Sejalan dengan pendapat Rusman bahwa kurikulum adalah seperangkat rencana dan pengaturan mengenai tujuan, isi, dan bahan pelarana serta bahan yang digunakan sebagai pedoman penyelenggaraan kegiatan pembelajaran untuk mencapai tujuan tertentu (Rusman,2009:3).

UU. No.20 tahun 2003 tentang System Pendidikan Nasional menyebutkan bahwa, kurikulum adalah seperangkat rencana dan pengaturan mengenai tujuan, isi, dan bahan pelajaran serta cara yang digunakan sebagai pedoman penyelenggaraan kegiatan pembelajaran untuk mencapai tujuan tertentu. 
Manajemen kurikulum adalah suatu system pengelolaan kurikulum yang kooperatif, komperhensif, sistemik, dan sistematik dalam rangka mewujudkan ketercapaian kurikulum. Dalam pelaksanaannya, manajemen berbasis sekolah (MBS) dan kurikulum tingkat satuan pendidikan (KTSP). Oleh karena itu, otonomi yang diberiukan pada lembaga pendidikan dalam mengelola kurikulum secara mandiri dengan memprioritaskan kebutuhan dan ketercapaian sasaran dalam visi dan misi lembaga pendidikan tidak mengabaikan kebijaksanaan nasional yang telah diterapkan.

Keterlibatan masyarakat dalam manajemen kurikulum dimaksudkan agar dapat memahami, membantu, dan mengontrol implementasi kurikulum, sehingga lembaga pendidikan selain dituntut kooperatif juga mampu mandiri dalam mengidentifikasi kebutuhan kurikulum, mendesak kurikulum mengendalikan serta melaporkan sumber dan hasil kurikulum, baik kepada masyarakat maupun pemerintah.

\section{RUANG LINGKUP, PRINSIP DAN} FUNGSI MANAJEMEN KURIKULUM

Manajemen kurikulum merupakan bagian integral dari Kurikulum Tingkat
Satuan Pendidikan (KTSP), Kurikulun 2013, dan Managemen Berbasis Sekolah (MBS). Lingkup manajemen kurikulum meliputi perencanaan, pengorganisasian, pelaksanaan dan evaluasi kurikulum. Pada tingkat satuan pendidikan kegiatan kurikulum lebih mengutamakan untuk merealisasikan dan merelevansikan antara kurikulum nasional (standar kompetensi/kompetensi dasar) dengan kebutuhan daerah dan kondisi sekolah yang bersangkutan, sehingga kurikulum tersebut merupakan kurikulum yang integritas dengan peserta didik maupun dengan lingkungan dimana sekolah itu berada. Sedangkan pada K13, kurikulum lebih mengarah pada pembentukan karakter siswa dan pembelajaran berpusat pada murid. Selain itu proses pembelajaran pada K13 menggunakan Model Pembelajaran berbasis Masalah (Problem Base Learning), Model Pembelajaran berbasis Penemuan (Discovery Learning) dan Model Pembelajaran berbasis Proyek (Project Base Learning).

Terdapat lima prinsip yang harus diperhatikan dalam melaksanakan manajemen kurikulum,yaitu:

a. Produktivitas, hasil yang akan diperoleh dalam kegiatan kurikulim merupakan aspek yang harus dipertimbangkan dalam manajemen 
kurikulum. Pertimbangan bagaimana agar peserta diduik dapat mencapai hasi belajar sesuai dengan tujuan kurikulum harus menjadi sasaran dalam manajemen kurikulum.

b. Demokratisasi, pelaksanaan manajemen kurikulum harus berasaskan demokrasi, yang menempatkan pengelolaan, pelaksanaan dan subjek didik pada posisi yang seharusnya dalam melaksanakan tugas dengan penuh tanggung jawab untuk mencapai tujuan kurikulum.

c. Kooperatif, untuk memperoleh hasil yang diharapkan dalam kegiatan manajemen kurikulum, perlu adanya kerja sama yang positif dari berbagai pihak yang terlibat.

d. Efektivitas dan efesiensi, rangkaian kegiatan manajemen kurikulum harus mempertimbangkan efektivitas dan efesiensi untuk mencapai tujuan kurikulum sehingga kegiatan manajemen kurikulum tersebut memberikan hasil yang berguna dengan biaya, tenaga dan waktu yang relative singkat.

e. Mengarahkan visi, misi dan tujuan yang ditetapkan dalam kurikulum, proses manajemen kurikulum harus dapat memperkuat dan mengarahkan visi, misi, dan tujuan kurikulum (Rusman, 2009:4).

Dalam proses pendidikan perlu dilaksanakan manajemen kurikulum agar perencanaan, pelaksanaan, dan evalusi kurikulum berjalan dengan efektif, efisien, dan optimal dalam memberdayakan berbagai sumber belajar, pengalaman belajar, maupun komponen kurikulum. Ada beberapa fungsi dari manajemen kurikulum di antara nya sebagai berikut:

a. Meningkatkan efisiensi pemanfaatan sumber daya kurikulum, pemberdayaan sumber maupun komponen kurikulum dapat ditingkatkan melalui pengelolaan yang terencana dan efektif.

b. Meningkatkan keadilan (equality) dan kesempatan pada siswa untuk mencapai hasil yang maksimal, kemampuan yang maksimal dapat dicapai peserta didik tidak hanya melalui kegiatan intrakurikuler, tetapi juga perlu melalui kegiatan ekstra dan kurikuler yang dikelola secara integritas dalam mencapai tujuan kurikulum.

c. Meningkatkan relevansi dan efektivitas pembelajaran sesuai 
dengan kebutuhan peserta didik maupun lingkungan, kurikulum yang dikelola secara efektif dapat memberikan kesempatan dan hasil yang relevan dengan kebutuhan peserta didik dan lingkungan sekitar.

d. Meningkatkan efektivitas kinerja guru maupun aktivitas siswa dalam mencapai tujuan pembelajaran,pengelolaan kurikulum yang professional, efektif, dan terpadu dapat memberikan motivasi pada kinerja guru maupun aktivitas siswa dalam pembelajaran.

e. Meningkatkan efisiensi dan efektivitas proses belajar mengajar, proses pembelajaran selalu dipantau dalam rangka melihat konsistensi antara desain yang telah direncanakan dengan pelaksanaan pembelajaraan.

Meningkatkan partisipasi masyarakat untuk membantu pengembangan kurikulum, kurikulum yang dikembangkan secara professional akan melibatkan masyarakat, khususnya dalam mengisi bahan ajar atau sumber belajar perlu disesuaikan dengan cirri khas dengan kebutuhan pembangunan daerah setempat (Rusman, 2009:5).

\section{MANAJEMEN PERENCANAAN \\ KURIKULUM}

Maksud dari manajemen dalam perencanaan kurikulum adalah kemampuan merencanakan dan mengorganisasikan kurikulum. Hal-hal yang perlu diperhatikan dalam proses perencanaan kurikulum adalah siapa yang bertanggung jawab dalam perencanaan kurikulum, dan bagaimana perencanaan kurikulum itu direncanakan secara professional.

Hal yang pertama dikemukakan berkenaan dengan kenyataan adanya gap atau jurang antara ide-ide strategi dan pendekatan yang dikandung oleh suatu kurikulumdengan usaha-usaha implementasinya. Gap ini disebabkan oleh masalah keterlibatan personal dalam perencanaan kurikulum. Keterlibtan personal ini banyak bergantung pada pendekatan kurikulum yang dianut.

Pada pendekatan yang bersifat "administrative approach" kurikulum direncanakan oleh pihak atasan kemudian diturunkan kepada instansi-instansi bawahan sampai kepaga guru-guru. Jadi from the top down, dari atas kebawah atas inisiatif administrator. Dalam kondisi ini guru-guru tidak dilibatkan. Mereka lebih bersifat pasif yaitu sebagai penerima dan pelaksana dilapangan. Semua ide, gagasan, dan inisiatif berasal dari pihak atasan (Oemar Hamalik, 2010:150). 
Sebaliknya pada pendekatan yang bersifat "grass roots approach" yaitu yang dimulai dari bawah, yakni dari pihak guruguru atau sekolah-sekolah secara individual dengan harapan bias meluas kesekolah lain. Kepala sekolah serta guru-guru dapat merencanakan kurikulum atau perubahan kurikulum karena melihat kekurangan dalam kurikulum yang berlaku. Mereka tertarik oleh ide-ide baru mengenai kurikulum dan bersedia menerapkannya disekolah mereka untuk meningkatkan mutu pelajaran.

Dengan bertindak dari pandangan bahwa guru adalah manager (the teacher as manager). J.G Owen sangat menekankan perlunya keterlibatan guru dalam perencanaan kurikulum. Guru harus ikut bertanggung jawab dalam perencanaan kurikulum karena dalam praktek mereka adalah pelaksana-pelaksana kurikulumyang sudah disusun bersama (Oemar Hamalik, 2010:151).

Masalah yang kedua, bagaimana kurikulum direncanakan secara professional, J.G Owen lebih menekankan pada masalah bagaimana menganalisis kondisi-kondisi yang perlu diperhatikan sebagai factor yang berpengaruh dalam perencanaan kurikulum.
Terdapat dua kondisi yang perlu dianalisis dalam perencanaan kurikulum:

a. Kondisi sosiokultural

Kemampuan professional manajerial menuntut kemampuan untuk dapat mengolah atau memanfaatkan berbagai sumber yang ada di masyarakat, untuk dijadikan narasumber. J.G Owen menyebutkan peran para ahli behavior sclence, karena kegiatan pendidikan merupakan nkegiatan behavioral dimana di dalamnya trjadi berbagai interaksi social antara guru dengan murid, murid dengan murid, dan atau guru dengan murid dengan lingkungannya.

b. Ketersediaan fasilitas

Salah satu penyebab gab antara perencanaan kurikulum dengan guruguru sebagai praktisi adalah jika kurikulum itu disusun tanpa melibatkan guru-guru, dan terlebih para perencana kurang atau bahkan tidak memperhatikan kesiapan guruguru dilapangan. Itulah sebabnya J.G Owen menyebutkan perlunya pendekatan "from the bottom up", yaitu pengembangan kurikulum yang 
berasal dari bawah ke atas (Oemar Hamalik, 2010:151).

Menurut Peter F. Olivia, Perencanaan kurikulum terjadi pada berbagai tingkatan, dan kurikulum pekerjaguru, pengawas, administrator, atau lainnya dapat terlibat dalam upaya kurikulum pada beberapa tingkat pada waktu yang sama. Semua guru yang terlibat dalam perencanaan kurikulum di tingkat kelas, guru yang paling berpartisipasi dalam kurikulum. Tingkat perencanaan dimana fungsi guru dapat dikonseptualisasikan sebagai sosok yang ditunjukan (Peter F. Olivia, 2004:46-47).

\section{MANAJEMEN ORGANISASI KURIKULUM}

Organisasi kurikulum adalah struktur program kurikulum yang berupa kerangka umum program-program pengajaran yang akan disampaikan kepada peserta didik. Struktur program ini merupakan dasar yang cukup esensial dalam pembinaan kurikulum dan berkaitan erat dengan tujuan program pendidikan yang hendak dicapai.

Salah satu aspek yang perlu dipahami dalam pengembangan kurikulum adalah aspek yang berkaitan dengan organisasi kurikulum. Organisasi kurikulum merupakan pola atau desain bahan kurikulum yang tujuannya untuk mempermudah siswa dalam mempelajari bahan pelajaran serta mempermudah siswa dalam melakukan kegiatan belajar sehingga tujuan pembelajaran dapat dicapai secara efektif.

Organisasi kurikulum sangat terkait dengan pengaturan bahan pelajaran yang ada dalam kurikulum, sedangkan yang menjadi sumber bahan npelajaran dalam kurikulum adalah nilai budaya, nilai social, aspek siswa dan masyarakat serta ilmu pengetahuan dan teknologi. Ada beberapa factor yang harus dipertimbangkan dalam organisasi kurikulum (Rusman, 2009:60), di antaranya berkaitan dengan ruang lingkup (scope), urutan bahan (sequence), kontinuitas,

keseimbangan dan keterpaduan (integrated).

Menurut Evelyn J. Sowel konsep organisasi kurikulum :

a. Subject matter designs

b. Society culture based designs/social functional and activities designed

c. Learner based designs

d. Other designs

\section{METODE PENELITIAN}


Penelitian ini menggunakan penelitian deskriptif dengan pendekatan kualitatif. Menurut Bog dan Taylor dalam Moleong menyatakan bahwa penelitian kualitatif adalah prosedur penelitian yang menghasilkan data deskriptif berupa katakata tertulis atau lisan dari orang-orang dan perilaku yang dapat diamati (Moleong, 1991:3).

Metode deskriptif di artikan sebagai prosedur atau cara cara mamecahkan masalah penelitian dengan memaparkan obyek yang diteliti ( seseorang, lembaga, masyarakat, dan lain-lain ), sebagaimana fakta yang aktual pada saat sekarang (Hadari Nawawi, 1992:67 ) .

Teknik pengumpulan data dengan observasi,wawancara dan dokumentasi. Teknik analisis data yaitu dengan reduksi data, penyajian data dan menarik kesimpulan.

\section{HASIL DAN PEMBAHASAN}

\section{MANAJEMEN PELAKSANAAN KURIKULUM}

Pembinaan kurikulum pada dasarnya adalah usaha pelaksanaan kurikulum di sekolah, sedangkan pelaksanaan kurikulum itu sendiri direalisasikan dalam proses belajar mengajar sesuai dengan prinsip-prinsip dan tuntutan kurikulum yang telah dikembangkan sebelumnya bagi suatu jenjang pendidikan atau sekolah-sekolah tertentu.

Pokok-pokok kegiatan tersebut dapat dikelompokkan menjadi 9 pokok kegiatan, yaitu :

a. Kegiatan yang berhubungan dengan tugas kepala sekolah

b. Kegiatan yang berhubungan dengan tugas guru

c. Kegiatan yang berhubungan dengan murid

d. Kegiatan yang berhubungan dengan proses belajar mengajar

e. Kegiatan-kegiatan ekstra kurikuler

f. Kegiatan pelaksanaan evaluasi

e. Kegiatan pelaksanaan pengaturan alat

f. Kegiatan dalam bimbingan dan penyuluhan

Kegiatan yang berkenaan dengan usaha peningkatan mutu professional guru

Pelaksanaan kurikulum dibagi menjadi dua tingkatan yaitu pelaksanaan kurikulum tingkat sekolah dan tingkat kelas. Dalam tingkat sekolah yang berperan adalah kepala sekolah, dan pada tingkat kelas yang berperan adalah guru. Walaupun dibedakan antara tugas kepala sekolah dan tugas guru dalam pelaksanaan kurikulum serta diadakan perbedaan dalam tingkat pelaksanaan 
administrasi, yaitu tingkat sekolah dan tingkat kelas, namun antara kedua tingkat dalam pelaksanaan administrasi kurikulum tersebut senantiasa bergandengan dan bersama-sama bertanggung jawab melaksanakan proses administrasi kurikulum.

Pengembangan kurikulum harus dilandasi oleh manajemen berdasarkan perimbangan-perimbangan multidimensional, yaitu :

1. Manajemen sebagai suatu disiplin ilmu sangat erat kaitannya dengan disiplin ilmu-ilmu lainnya, seperti filsafat, psikologi, social budaya, sosiologi dan teknoligi, bahkan ilmu manajemen banyak mendapat konstribusi dari ilmu-ilmu yang lain. Banyak teori, konsep dan pendekatan dalam ilmu manajemen member masukan teoritik dan fundamental bagi pengembangan kurikulum.

2. Para pengembang kurikulum mengikuti pola dan alur piker yang singkron dengan pola dan struktur berpikir dalam manajemen. Proses pengembangan tersebut sejalan dengan proses manajemen yakni kegiatan pengembangan dimulai dari proses

perencanaan ,pengorganisasian, implementasi dan control serta perbaikan.

3. Implementasi kurikulum sebagai bagian integral dalam pengembangan kurikulum yang membutuhkan konsep-konsep, prnsip-prinsip dan prosedur serta pendekatan dalam manajemen. Implementasi kurikulum menuntut pelaksanaan pengorganisasian, koordinasi motivasi, pengawasan, system penunjang serta system komunikasi dan monitoring yang efektif, yang berasal dari ilmu manajemen.

4. Pengembangan kurikulum sangat erat kaitannya dengan kebijakan dibidang pendidikan, yang bersumber dari kebijakan pembangunan nasional, kebijakan daerah, serta berbagai kebijakan sektoral.

\section{PENERAPAN KURIKULUM}

Penerapan manajemen kurikulum K13 ini terkhusus pada PAUD AS- Sakinah belum terlaksana secara maksimal. Kurangnya pemahaman guru pada K13 serta pola pikir guru dan kepala sekolah disana yang masih berpendapat metode konvensional lebih tepat untuk mendidik . Sedangkan yang kita ketahui bahwa metode 
konvensional ini tidak sesuai dengan K13 yang seharusnya siswa yang aktif dalam pembelajaran dan guru hanya sebagai fasilitator yaitu mengamati dan membantu anak menjelaskan.

Pelaksanaan kurikulum yang dipakai PAUD As-Sakinah ini adalah penggabungan antara K13 dan KTSP ,disini tetap menggunakan format $\mathrm{k} 13$ dalam pebuatan RPH, RPM, dan menggunakan tema, subtema, kompetensi dasar, kompetensi inti sesuai dengan K13, namun dalam penerapan pembelalajaran lebih banyak menggunakn kurikulum tingkat satuan pendidikan (KTSP). Dalam penerapan pelaksanaannya Paud ini menggunakan model pembelajaran area, yang mana disini anak mempunya 1 ruangan besar dimana dalam ruangan itu anak dikumpulkan dan diberikan pembelajaran dengan pembelajaran konvensional . Dalam pembelajaran itu guru lebih aktif dan menerangkan anak ,selain itu media pembelajaran disini sangat terbatas sehingga dalam tugas mewarnai anak akan dikelompokan dalam pengerjaannya, walaupun tugas itu bersifat individual.

\section{KESIMPULAN}

Manajemen kurikulum adalah seperangkat kemampuan dalam mengelola kurikulum, mulai dari perencanaan kurikulum hingga evaluasi kurikulum. Kurikulum yang baik adalah kurikulum yang mengikuti perkembangan ilmu dan teknologi yang berbasis masyarakat. Kegagalam dalam manajemen sebuah kurikulum akan berakibat fatal pada keberhasialan pendidikan itu sendiri. Oleh karena itu, setiap penanggung jawab lembaga pendidikan dan seluruh stakeholder pendidikan harus memiliki visi yang sama dalam merencanakan, mengorganisasi, melaksanakan, dan mengevaluasi sebuah kurikulum. Karena dalam penerapan dan pelaksanaan kurikulum itu sendiri perlu pertimbangan yang matang dari pihak sekolah ,karna harus menyesuaikan dengan kondisi dan keadan ,terkhusus nya pada PAUD As-Sakinah yang dalam pelaksanaan nya yang masih tetap menggunakan KTSP

\section{DAFTAR PUSTAKA}

Arifin, Zainal, 2011. Konsep dan Model Pengembangan Kurikulum, Cet. I; Bandung: PT. Remaja Rosdakarya.

Depdiknas. (2003). Undang-Undang Nomor 20 Tahun 2003 tentang Sistem Pendidikan Nasional, Jakarta: Departemen Pendidikan Nasional 
PERNIK Jurnal PAUD, VOL 1 NO.1 September 2018

Hamalik, Oemar, 2010. Manajemen Pengembangan Kurikulum, Cet. IV; Bandung : PT. Remaja Rosdakarya.

Hadari Nawawi, 1993. Pendidikan dalam Islam, Surabaya : Al-Ikhlas.

Meleong, J.2007. Metode Penelitian Ilmiah dan Dasar Metode Teknik, Transito, Bandung.

Olivia, Peter F., 2004. Development The Curriculum, edisi IV New York: Pearso Education, inc.
Rusman, 2009. Manajemen Kurikulum, Seri II; Jakarta : PT. Raja Grafindo Persada.

Robert, Stake E, 1967. The Countenance of Education Evalution, Teacher College.

Sowell, Evelyn J., Curriculum An Integrative Introduction, Edisi III; New York : Pearso Educat 
PERNIK Jurnal PAUD, VOL 1 NO.1 September 2018 